\title{
Analisis Pertanggungjawaban Direksi Perusahaan Perbankan Dalam Kerugian Yang Dialami Oleh Nasabah
}

\author{
${ }^{1}$ Tryas Noor Lazuard, ${ }^{2}$ Widya Olyvia Purba \\ Mahasiswa Pascasarjana Fakultas Hukum Universitas Indonesia \\ Korespondensi: tryas.noor@ui.ac.id, widya.olyvia@ui.ac.id
}

\begin{abstract}
The accountability of the Board of Directors in a company often becomes a question mark in the community, especially in banking companies where the bank itself has become part of the daily needs of the people in Indonesia. The responsibility of the board of directors can be in the form of legal liability, both criminal and civil. However, there are other alternatives that can be used in solving the problem of bank customer losses, namely through deliberation
\end{abstract}

Keywords: Board of Directors, Banking Company, Accountability

Abstrak. Pertanggungjawaban Direksi dalam suatu perusahaan kerap menjadi tanda tanya di tengah masyarakat terutama dalam perusahaan perbankan yang dimana bank sendiri sudah menjadi bagian dari kebutuhan sehari-hari masyarakat di Indonesia. Pertanggungjawaban direksi dapat berupa pertanggungjawaban secara hukum baik pidana maupun perdata namun adapula alternative lain yang dapat digunakan dalam penyelesaian masalah kerugian nasabah perbankan yaitu dengan permusyawaratan.

Kata Kunci: Direksi, Perusahaan Perbankan, Pertanggungjawaban

\section{PENDAHULUAN}

Setiap negara harus tetap mempertahankan segi perekonomiannya agar pertumbuhan serta perkembangan ekonomi negara tersebut tetap terjaga dan negara tersebut tetap hidup. Pertumbuhan dan perkembangan ekonomi pada suatu negara membawa pengaruh besar bagi kesejahteraan masyarakatnya. Oleh karena itu, demi mempertahankan dan menjaga pembangunan ekonomi nasional pada suatu negara dibutuhkan pemasukan baik dari dalam negeri maupun negara-negara lain untuk menjaga sumber daya pada suatu negara tetap ada dan menjaga negara agar tetap hidup dan berkembang. Industri perbankan telah mengalami perubahan besar dalam beberapa tahun terakhir. Industri ini menjadi lebih kompetitif karena deregulasi peraturan. Saat ini, bank memiliki fleksibilitas pada layanan yang mereka tawarkan, lokasi tempat mereka beroperasi, dan tarif yang mereka bayar untuk simpanan deposan. Dalam Undang-Undang RI No. 10 Tahun 1998 tentang Perbankan (pasal 1 ayat 2), menyebutkan bahwa bank adalah sebuah badan usaha yang menghimpun dana dari masyarakat dalam bentuk simpanan dan menyalurkannya kepada masyarakat dalam bentuk kredit dan atau bentuk-bentuk lain dengan tujuan untuk meningkatkan taraf hidup orang banyak. Lembaga keuangan tersebut adalah bank. Pendirian bank sendiri bertujuan untuk menunjang pelaksanaan pembangunan nasional dalam rangka meningkatkan pemerataan, pertumbuhan ekonomi, dan stabilitas nasional ke arah peningkatan taraf kehidupan masyarakat. Dana yang dibutuhkan bank tersebut dapat dihasilkan dari dana bank itu sendiri (dana intern) dan dana dari pihak ketiga (dana ekstern). Sumber dana yang berasal dari bank itu sendiri dapat berupa setoran modal/penjualan saham, pemupukan cadangan, laba yang ditahan, dan lain-lain. Secara umum dapat dikatakan bahwa bank adalah sebuah lembaga intermediasi keuangan umumnya didirikan dengan kewenangan untuk menerima simpanan uang, meminjamkan uang, 
dan menerbitkan promes atau yang dikenal sebagai banknote, bank juga menerima kredit, menerima simpanan dari masyarakat dalam bentuk giro, deposito berjangka dan tabungan, yang kemudian dikelola dengan cara menyalurkannya dalam bentuk investasi dan kredit kepada badan usaha, swasta, atau pemerintah.

Menurut Otoritas Jasa Keuangan, upaya pengawasan terhadap perusahaan pada sektor keuangan dapat diwujudkan dengan adanya implementasi praktik tata kelola perusahaan atau Good Corporate Governance (GCG). Pengawasan GCG yang diterapkan pada perusahaan diharapkan dapat meningkatkan kinerja perusahaan baik secara finansial maupun operasional. Perusahaan yang melaksanakan GCG akan memberikan dampak yang positif bagi perusahaan salah satunya akan dapat meningkatkan kesejahteraan pemilik atau pemegang saham melalui menaikkan nilai perusahaan di mata investor. GCG juga dapat mempermudah diperolehnya dana pembiayaan yang lebih murah menurut Forum Corporate Governance in Indonesia (FCGI). GCG juga mendorong semua faktor internal dan eksternal dalam perusahaan agar lebih baik dalam menjalankan manajemennya. GCG juga kunci sukses perusahaan untuk menghasilkan keuntungan dan tetap bertahan dan bertumbuh.

\section{METODE PENELITIAN}

Penyusunan metode penelitian ini didasarkan pada metode penelitian dan penulisan hukum. Dalam penelitian ini jenis penelitian yang digunakan adalah penelitian hukum normatif (legal research). Untuk bahan hukum penulis menggunakan tiga jenis bahan hukum, yaitu bahan hukum primer, bahan hukum sekunder dan bahan hukum tingkat tersier. Hasil wawancara dengan narasumber dan informan turut mendukung penelitian ini.

Dalam penelitian ini, adapun teknik pengumpulan data yang digunakan adalah dengan menggunakan pendekatan kualitatif dengan melakukan studi kepustakaan serta jenis data yang akan digunakan adalah data sekunder yang berupa bahan hukum primer dan bahan hukum sekunder sebagai berikut:

a) Data sekunder, yakni data yang diperoleh dari penelitian kepustakaan dan dilaksanakan dengan menginventarisasi seluruh peraturan dan data yang memiliki keterkaitan dengan obyek penulisan penelitian ini.

b) Sumber bahan hukum primer diperoleh dari peraturan perundang-undangan terkait. Selain itu Penulis juga melakukan studi terhadap Putusan-Putusan Pengadilan, baik itu Pengadilan Negeri, Pengadilan Tinggi, Mahkamah Agung, termasuk juga Putusan Mahkamah Konstitusi.

c) Sumber bahan hukum sekunder diperoleh melalui studi pustaka terhadap berbagai karya ilmiah dan pendapat sarjana yang terdapat dalam buku-buku atau literatur terkait pembahasan dalam penelitian, artikel-artikel baik dalam media cetak maupun yang diperoleh dengan cara pengaksesan internet.

\section{PEMBAHASAN}

Perseroan Terbatas sebagai subyek hukum merupakan orang buatan (artificial person) karena itu tidak dapat melakukan tindakan sendiri, oleh sebab itu harus diwakili seseorang atau organ yang bertindak untuk dan atas nama perseroan terbatas. Organ tersebut adalah direksi yang akan melakukan pengurusan terhadap perseroan terbatas karena itu akan melakukan perbuatan hukum untuk dan atas nama perseroan. Direksi adalah organ yang mewakili perseroan selaku subyek hukum yang mandiri (persona standi judicio). Perseroan terbatas dipandang sebagai subyek hukum yang mandiri dilepaskan dari manusia-manusia yang terkandung di dalamnya (separate legal personality). Berdasarkan Pasal 1 angka (5) Undang- Undang Nomor 40 Tahun 2007 tentang Perseroan Terbatas (UUPT) menyebutkan bahwa pengertian Direksi dalam Perseroan Terbatas (Perseroan) adalah organ Perseroan yang berwenang dan bertanggung jawab penuh atas pengurusan Perseroan untuk 
kepentingan Perseroan, sesuai dengan maksud dan tujuan Perseroan serta mewakili Perseroan, baik di dalam maupun di luar pengadilan sesuai dengan anggaran dasar. Kewenangan untuk mewakili tersebut adalah untuk dan atas nama perseroan, bukan atas nama dari Direksi, tetapi mewakili perseroan. Jika perseroan pailit dan diakibatkan karena kelalaian atau kesalahan Direksi dan kekayaan perseroan tidak cukup untuk menutup kerugian akibat kepailitan tersebut, setiap anggota direksi secara tanggung renteng bertanggung jawab atas kerugian tersebut. Dapat dikatakan hanya Direksi yang dapat diminta atau digugat secara tanggung jawab pribadi apabila terbukti melakukan kesalahan atau kelalaian yang menimbulkan kerugian bagi perseroan berdasarkan Pasal 97 Undang-Undang nomor 40 tahun 2007 tentang Perseroan Terbatas.

Namun jika dipelajari secara seksama, maka diantara sekian banyak perubahan yang diatur dalam Undang-Undang nomor 40 tahun 2007 tentang Perseroan Terbatas, terdapat pokok-pokok perbedaan yang layak untuk dicermati, yaitu tanggung jawab perseroan tidak hanya pada Direksi saja, melainkan sampai dengan Komisaris. Komisaris pada umumnya bertugas untuk mengawasi kebijaksanaan Direksi dalam mengurus perseroan serta memberikan nasihat-nasihat kepada Direksi, demikian menurut pasal 108 Undang-Undang nomor 40 tahun 2007 tentang Perseroan Terbatas. Tugas pengawasan itu bisa merupakan bentuk pengawasan preventif atau represif. Pengawasan preventif adalah melakukan tindakan dengan menjaga agar tidak terjadi hal-hal yang tidak diinginkan yang akan merugikan perseroan, misalnya untuk beberapa perbuatan dari Direksi yang harus dimintakan persetujuan Komisaris, apakah hal itu sudah dilaksanakan atau belum. Dalam hal ini Komisaris harus selalu mengawasinya. Sedangkan yang dimaksud dengan pengawasan represif ialah pengawasan yang dimaksudkan untuk menguji perbuatan Direksi, apakah semua perbuatan yang dilakukan itu tidak menimbulkan kerugian bagi perseroan dan tidak bertentangan dengan Undang-Undang dan anggaran dasar. Pada Pasal 114 ayat (2) Undang-Undang Nomor 40 tahun 2007 tentang Perserosan Terbatas memberikan kewajiban pada Komisaris agar dengan itikad baik dan penuh tanggung jawab menjalankan tugas untuk kepentingan dan usaha perseroan. Bahkan Undang-Undang nomor 40 tahun 2007 tentang Perseroan Terbatas memungkinkan Direksi ataupun Komisaris untuk digugat ke pengadilan oleh pemegang saham, bila keduanya terbukti melakukan kesalahan atau kelalaian yang menimbulkan kerugian bagi perseroan.

Organ Perseroan Terbatas menurut Undang-Undang Nomor 40 tahun 2007 terdiri dari rapat umum pemegang saham, direksi, dan dewan komisaris. Ketiga organ perseroan di atas mempunyai hak absolut dan hak relatif. Hak absolut adalah hak yang memberi kewenangan bagi pemiliknya untuk berbuat sesuatu atau tidak berbuat sesuatu. Sedangkan hak relatif adalah kewenangan menuntut pemegang hak terhadap orang tertentu yang terlibat dalam hubungan hukum tertentu, misalnya antara kreditur dan debitur dalam perjanjian kredit. Dalam hal ini, khusus untuk direksi, sesuai pendapat M. Yahya Harahap dikategorikan 2 (dua) macam kewajiban, yaitu kewajiban administratif dan kewajiban juridis. Kedua kewajiban ini semestinya dipahami oleh direksi agar dapat melakukan tugas-tugasnya dengan baik. Direksi sebagai organ kepercayaan Perseroan wajib menjalankan tugas pengurusan Perseroan dengan berpegang teguh pada kepercayaan yang diterimanya (fiduciary duty). Fiduciary duty artinya suatu keadaan dimana sesorang bertindak untuk dan atas nama pihak lain dalam suatu urusan yang timbul karena hubungan kepercayaan. Dengan demikian seseorang dikatakan mempunyai fiduciary duty manakala dia dipercayakan berbuat sesuatu untuk kepentingan orang lain utau untuk kepentingan pihak ketiga. Direksi dapat dimintai pertanggungjawaban secara pribadi, jika terbukti melanggar prinsip fiduciary duty dalam menjalankan 
kepengurusan Perseroan yang mengakibatkan kerugian terhadap Perseroan. Seringkali suatu keputusan yang diambil oleh Direksi dapat menyebabkan kerugian bagi Perseroan. Baik itu disebabkan oleh Perseroan itu sendiri, atau juga bisa disebabkan dari tindakan pihak lawan. Pertanggungjawaban anggota Direksi tidak terbatas hanya pada pertanggungjawaban perdata namun apabila dapat dibuktikan adanya perbuatan pidana seperti tindak korupsi maka anggota Direksi dapat dipertanggungjawabkan secara pidana.

Kewenangan Direksi itu tidak terbatas dan tidak bersyarat, sepanjang tidak bertentangan dengan Undang-undang, anggaran dasar Perseroan, keputusan RUPS serta peraturan perundangan lain yang berlaku. Tanggung jawab Direksi pada dasarnya dilandasi oleh 2 (dua) prinsip yang penting, yaitu prinsip yang lahir karena tugas dan kedudukan yang dipercayakan kepadanya oleh Perseroan dan prinsip yang merujuk kepada kemampuan serta kehatihatian tindakan Direksi. Kedua prinsip ini menuntut Direksi untuk bertindak secara hati-hati dan disertai dengan itikad baik, semata-mata untuk kepentingan dan usaha Perseroan, kewajiban tersebut ditegaskan dalam Pasal 85 ayat (1) UUPT. Adanya ketergantungan Perseroan kepada Direksi sebagai organ yang dipercayakan oleh Undang-undang untuk melakukan pengurusan jalannya Perseroan, dan Perseroan adalah sebab bagi keberadaan (raison d'etre) Direksi, karena apabila tidak ada Perseroan, maka juga tidak ada Direksi. Badan hukum adalah suatu realitas sesungguhnya, sama seperti sifat manusia dalam pergaulan hukum. Teori ini pada dasarnya menggambarkan badan hukum sebagai sesuatu yang tidak berbeda sebagai subyek hukum. Teori ini diseut dengan Theory Organ. Perseroan merupakan "separate legal entity" dari pemegang saham. Harta pemegang saham terpisah dengan harta kekayaan perseroan, demikian pula sebaliknya. Ketika perseroan sudah menjadi badan hukum, maka pengadilan biasanya tidak akan memeriksa siapa di balik perseroan, atau siapa yang mendirikan atau mengontrol perseroan. Konsep pemisahan antara perseroan dengn pendiri atau pemegang saham perseroan menghasilkan akibat hukum terbatasnya tanggung jawab pemegang saham. Anggaran Dasar dapat memuat pembatasanpembatasan tertentu yang mengikat Direksi. Merupakan hal yang lazim Anggaran Dasar mengatur bahwa perbuatan-perbuatan hukum tertentu dari Perseroan hanya boleh dilakukan oleh Direksi setelah mendapat persetujuan RUPS atau Dewan Komisaris. Dewan Komisaris tidak mempunyai peran dan fungsi eksekutif, sekalipun Anggaran Dasar menentukan bahwa perbuatan-perbuatan Direksi tertentu memerlukan persetujuan Dewan Komisaris namun persetujuan dimaksud bukan pemberian kuasa dan bukan pula perbuatan pengurusan. Apabila Direksi melanggar ketentuan UUPT atau Anggaran Dasar yang mewajibkan Direksi mendapatkan persetujuan terlebih dahulu dari RUPS atau Dewan Komisaris maka harus dibedakan antara akibat ke dalam (interne werking) dan akibat ke luar (externe werking) perbuatan hukum yang dilakukan Direksi tersebut. Berkenaan dengan akibat ke luar, UUPT mengenal asas hukum bahwa pihak ketiga yang beritikad baik harus dilindungi. Setiap anggota Direksi secara tanggung renteng atas akibat kepailitan Perseroan yang terjadi karena kesalahan atau kelalaian Direksi sebagaimana dinyatakan dalam Pasal 104 ayat (2) dan ayat (3) UUPT adalah konsekuensi logis dan wajar dari tugas pengurusan Perseroan yang oleh undangundang dipercayakan kepada Direksi sehingga melahirkan fiduciary responsibility pada Direksi. Oleh karena itu tidak salah apabila dikatakan bahwa antara Perseroan dan Direksi terdapat hubungan fidusia atau kepercayaan (fiduciary relationship) yang melahirkan fiduciary duty bagi Direksi yaitu duty of loyalty and good faith dan duty of care, skill and diligence.

Ditegaskan dalam UUPT Pasal 97 ayat (2) dan ayat (3), Direksi hanya dapat di pertanggung jawabkan atas kerugian Perseroan 
apabila kerugian tersebut disebabkan oleh kesalahan atau kelalaian Direksi karena tidak menjalankan tugasnya dengan itikad baik dan penuh tanggung jawab. Direksi tetap bebas untuk tidak melakukan perbuatan hukum yang bersangkutan bahkan Direksi wajib mengurungkan rencananya bilamana perbuatan tersebut dapat merugikan Perseroan. Setiap kegagalan atau kerugian yang dialami perusahaan dapat ditelusuri dari keputusan Direksi sebagai pengemban fiduciary duty. Keputusan Direksi dipandang dari dua aspek yaitu aspek integritas yang disebut dengan duty of loyalty dan aspek teknis administratif yang dikonseptualisasikan sebagai duty of care yang berujung pada pemenuhan kepentingan pemegang saham. Kebanyakan negara-negara penganut common law memandang business judgement rule sebagai bagian dari duty of care, skill and diligence. Doktrin business judgement rule dapat memberikan imunitas bagi Direksi apabila keputusannya salah dan menimbulkan kerugian. Namun demikian, business judgement rule tidak dapat dipakai Direksi untuk lepas dari tanggung jawab atas kerugian perusahaan yang disebabkan oleh kelalaian atau kegagalannya memenuhi prinsip business judgement rule. Kesalahan atau kelalaian dalam penerapan doktrin business judgement rule juga dapat menjadi preseden buruk dan berpengaruh pada iklim investasi, karena investor dan pelaku ekonomi pada umumnya menggunakan bentuk perusahaan Perseroan Terbatas sebagai bentuk usaha di Indonesia, juga dapat merugikan anggota Direksi secara pribadi, para pemegang saham, anggota Dewan Komisaris dan pihak ketiga yang beritikad baik.

\section{KESIMPULAN}

Wewenang Direksi tidak terbatas dan tidak bersyarat, sepanjang tidak bertentangan dengan Undang-undang, anggaran dasar Perseroan, keputusan RUPS dan peraturan perundang-undangan lainnya yang berlaku. Direksi dapat dimintai pertanggungjawaban secara pribadi apabila terbukti melanggar asas fidusia dalam pengurusan Perseroan yang mengakibatkan kerugian bagi Perseroan. Seringkali keputusan yang diambil oleh Direksi dapat merugikan perusahaan. Baik itu disebabkan oleh Perseroan sendiri atau bisa juga karena ulah pihak lawan.

Direksi hanya dapat dimintai pertanggungjawaban atas kerugian Perseroan jika kerugian tersebut disebabkan oleh kesalahan atau kelalaian Direksi karena tidak melaksanakan tugasnya dengan itikad baik dan penuh tanggung jawab. Tanggung jawab Direksi tidak terbatas pada tanggung jawab perdata, tetapi jika dapat dibuktikan adanya kejahatan-kejahatan pidana seperti korupsi maka direksi dapat dituntut secara pidana. Wewenang Direksi tidak terbatas dan tidak bersyarat, sepanjang tidak bertentangan dengan Undang-undang, anggaran dasar Perseroan, keputusan RUPS dan peraturan perundangundangan lainnya yang berlaku.

Meskipun dilihat dari kacamata hukum, Direksi yang bersangkutan dapat dimintakan pertanggungjawaban hukum baik secara pidana maupun perdata sesuai dengan peraturan Undang-Undang yang berlaku berdasatkan kelalaian yang dilakukan oleh direksi yang bersangkutan. Menginat pentingnya citra dan meninjau tingkat kerugian yang akan timbul dan jelas berdampak pada perusahaan dan sejajaran petingginya dalam hal penyelesaian pertanggungjawaban direksi perusahaan apabila direksi dari perusahaan tersebut dimintakan pertanggungjawaban secara hukum terlebih lagi dalam rana pidana maka adapun hal yang dapat dilakukan oleh perusahaan adalah dengan penyelesaian masalah dalam hal ini kerugian nasabah perbankan dengan cara permusyawaratan yang umumnya dilakukan dengan melaksanakan mediasi dan/atau negosiasi antara pihak perusahaan perbankan yang dalam hal ini termasuk Direksi yang bersangkutan dengan pihak nasabah yang dirugikan.

SARAN

Adapun saran yang dapat kami berikan selaku para penulis dalam hal pertanggungjawaban direksi dalam hal kerugan 
nasabah adalah pentingnya itikad baik dari perusahaan perbankan untuk menyelesaikan masalah dengan nasabah yang dirugikan.

\section{DAFTAR PUSTAKA}

Ahmad Sulaiman, 2007, Aspek Hukum Kerugian PT BUMN (Persero) Terkait Unsur Tindak Pidana Korupsi Merugikan Keuangan Negara, Tesis, Jakarta: Universitas Indonesia.

Andi Nova Bukit, 2019, Pertanggungjawaban Bank Terhadap Hak Nasabah Yang Dirugikan Dalam Pembobolan Rekening Nasabah (Studi Di Pt. Bank Rakyat Indonesia Tbk, Kantor Cabang Medan Gatot Subroto), Jurnal Ius Constituendum Volume 4 Nomor.

Arifianto Ibrahim, 2013, Tanggung Jawab Direksi PERSERO Dalam Hal Terjadi Kerugian (Studi Kasus Pada Sewa Menyewa PT.Merpati Nusantara Airlines dengan Thirdstone Aircraft Leasing Group), Tesis, Yogyakarta: Universitas Islam Indonesia.

Budiarto, Agus, 2009, Kedudukan Hukum \& Tanggung Jawab Pendiri Perseroan Terbatas, Bogor: Gahlia Indonesia.

Ferdinan Agustinus, 2013, Tanggung Jawab Pribadi Anggota Direksi Perseroan Terbatas Menurut Undang-Undang Perseroan Terbatas (Tinjauan Yuridis Terhadap Putusan Mahkamah Agung Nomor : 3754 K/Pdt/2001), Tesis, Depok: Universitas Indonesia.

Harahap, Yahya, 2009, Hukum Perseroan Terbatas Jakarta: Sinar Grafika.

Harris, Freddy, dan Teddy Anggoro, 2010, Hukum Perseroan Terbatas, Kewajiban Pemberitahuan Oleh Direksi, Bogor: Penerbit Ghalia Indonesia.

Liyandri R. Tarigan, Chatarina Yekti Prawihatmi, 2017, Peran Mekanisme Good Corporate Governance Terhadap Kinerja Keuangan Perbankan Yang Terdaftar Di Bursa
Efek Indonesia, Jurnal Riset Ekonomi dan Bisnis Vol. 10 No. 2.

Mayson, Stephen W., Derek French, \& Christopher L Ryan, 1996, Company Law London: Blackstone Press Limited, 1996.

Mertokusumo, Sudikno, 1986, Mengenal Hukum (Suatu Pengantar), Yogyakarta: Liberty.

Monica Caecilia Darmawan, 2019, Perlindungan Hukum bagi Pemegang Saham Minoritas yang Dirugikan Akibat Direksi Melakukan Kesalahan atau Kelalaian, Jurnal Jurist-diction Vol 2 No. 3.

Rika Silviana, 2004, Tinjauan Yuridis Tanggung Jawab Direksi Perusahaan Public Terhadap Pelanggaran Prinsip Keterbukaan Informasi Di Pasar Modal, Tesis, Depok: Universitas Indonesia.

Rudhi Prasetya, 1987, Kedudukan, Peran dan Pertanggungjawaban Pengurus Perseroan Terbatas, Makalah, (makalah disampaikan pada Seminar Hukum Dagang, diselenggarakan Badan Pembinaan Hukum Nasional), Jakarta.

Shasha Adisa Putrianti, 2015, Pertanggungjawaban Anggota Direksi Bumn (PT Persero) Dalam Penerapan Prinsip Kehati-Hatian Di Dalam Pengambilan Keputusan Yang Dapat Berdampak Kerugian Bagi Perseroan (Studi Putusan Mahkamah Agung Nomor 2470k/Pid/2006), Tesis, Jakarta: Universitas Indonesia.

Sri Dewi M. Tambunan, 2009, Dilema Tanggung Jawab Direksi PT. BUMN Atas Kerugian Perusahaan, Tesis, Depok: Universitas Indonesia.

Sulaiman, Aiman Nariman M., 2001, Director's Duties and Corporate Governance, Kuala Lumpur: Sweet \& Maxwell Asia.

Sumarto, 2005, Tanggung jawab pribadi direksi perseroan terbatas sebelum 
Terakreditasi Peringkat 5 (No. SK: 85/M/KPT/2020)

pendaftaran dan pengumuman menurut Undang-Undang Nomor 1 Tahun 1995 tentang Perseroan Terbatas, Tesis, Jakarta: Universitas Indonesia.

Tiffany Valencya, 2014, Tanggung Jawab Direksi Perseroan Terbatas Yang Melakukan Tindak Pidana Korupsi (Studi Kasus Putusan Mahkamah Agung Nomor 152pk/Pid.Sus/2010), Tesis, Jakarta: Universitas Indonesia.

Wicaksono, Frans Satro, 2009, Tanggung Jawab Pemegang Saham, Direksi \& Komisaris Perseroan Terbatas (PT), Jakarta: Trasmedia Pustaka.

Yuherman, 2004, Pembatasan dan Tanggung Jawab Direksi Dalam Kepailitan Perseroan Terbatas, Tesis, Jakarta: Universitas Indonesia. 